\section{Pseudo Chediak-Higashi Anomaly}

\section{Psödo-Chediak-Higashi Anomalisi}

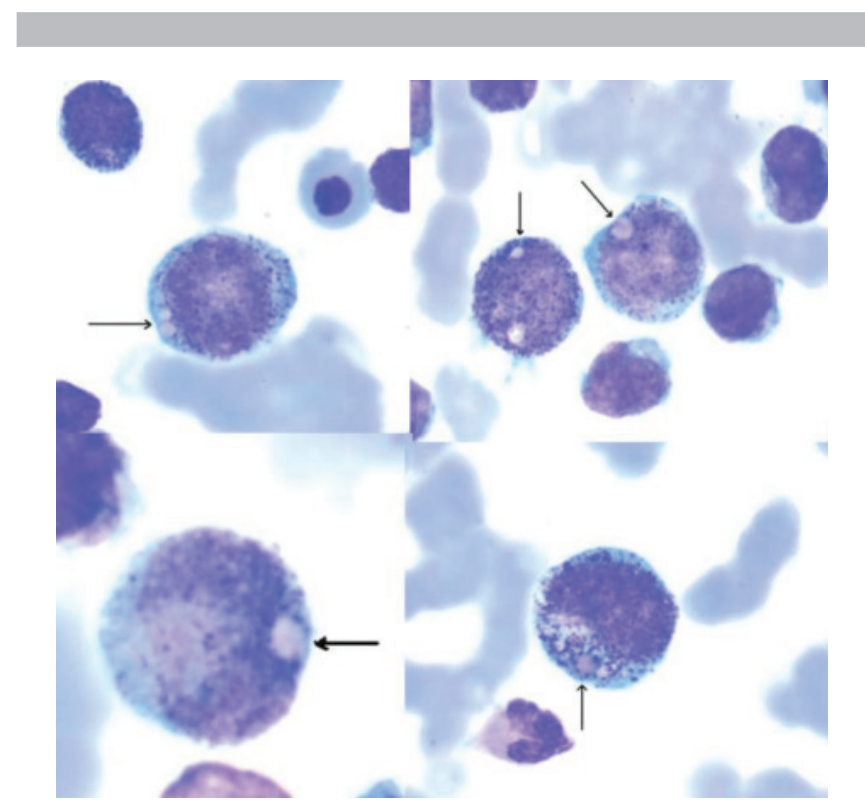

Figure 1: Wright staining of a bone marrow smear shows large eosinophilic granules ( $\mathrm{PCH}$ granules) within the blast and myeloid cells.

\section{Zekai Avcı1, Barış Malbora², Namık Özbek3 \\ ${ }^{1}$ Başkent University Faculty of Medicine, Department of Pediatric, Hematology, Ankara, Turkey \\ ${ }^{2}$ Dr. Sami Ulus Maternity and Children's Hospital, Department of Pediatric Hematology, Ankara, Turkey \\ ${ }^{3}$ Başkent University Faculty of Medicine, Department of Pediatric Hematology and Oncology, Ankara, Turkey}

Address for Correspondence: Barış MALBORA, M.D.,

Dr. Sami Ulus Maternity and Children's Hospital, Department of Pediatric Hematology, Ankara, Turkey

Gsm: +90 5336413841 E-mail: barismalbora@gmail.com

Received/Geliş tarihi : October 24, 2011

Accepted/Kabul tarihi : February 21, 2012
A 9-year-old girl was admitted to hospital with a 1-month history of fever, weight loss, epistaxis, and abdominal pain. The girl's parents were non-consanguineous. Her medical history was unremarkable. Upon admission she weighed 27 $\mathrm{kg}$ (25th-50th percentile), was $131 \mathrm{~cm}$ tall (50th percentile), and was pale. Physical examination showed multiple cervical and inguinal microlymphadenopathies, without hepatosplenomegaly. Complete blood count findings were as follows: hemoglobin $7.9 \mathrm{~g} / \mathrm{dL}$; white blood cell count: 12.3×109/L; platelet count: $9.2 \times 109 / \mathrm{L}$. Her peripheral blood smear showed $43 \%$ blast cells, $42 \%$ lymphocytes, $8 \%$ monocytes, $6 \%$ neutrophils, and $1 \%$ eosinophils. Bone marrow aspiration showed hypercellularity, with $45 \%$ myeloblasts, $15 \%$ promyelocytes, $7 \%$ myelocytes, $4 \%$ metamyelocytes, $1 \%$ eosinophils, $2 \%$ neutrophils, $15 \%$ lymphocytes, and $11 \%$ normoblasts. Wright staining of a bone marrow smear showed large $(2-4 \mu \mathrm{m})$ round-to-oval, hyaline-structured eosinophilic granules (pseudo Chediak-Higashi [PCH] granules) within $15 \%$ of the blast cells, promyelocytes, and myelocytes (Figure). Some of the granules appeared to be in vacuoles, giving them a haloed appearance. The blasts were myeloperoxidase (MPO)-positive, and periodic acidSchiff (PAS)-negative. Immunophenotypic analysis of the leukemic cells showed proliferation of CD13 (75\%), CD33 (59\%), CD34 (95\%), CD117 (68\%), and HLA DR (44\%).

The patient was diagnosed with as type M2 acute myeloid leukemia (AML). Cytogenetic analysis of a bone marrow sample showed 45,XX,t(8;21)(q22;q22). Cerebrospinal fluid biochemistry was normal, without detectable cells, based on cytocentrifuge analysis. The patient was treated according to the Berlin-Frankfurt-Munster (BFM) 2004 treatment protocol for AML. She is being followed without chemotherapy for two years and she does not have any problems.

PCH anomaly was first described in 1964 by Didisheim et al. [1]. Later, VanSlyck and Rebuck [2] reported similar granules in the leukemic cells of 2 patients with AML-M4, and used the term, pseudo Chediak-Higashi anomaly of acute leukemia, because of the resemblance of the granules to those seen in patients with inherited Chediak-Higashi syndrome. PCH anomaly is characterized by the presence of large cytoplasmic eosinophilic granules in leukemic blast cells, promyelocytes, and myelocytes. It is most often observed in patients with AML subtypes M2, M3, M4, and M5, but it is also associated with chronic myeloid leukemia, myelodysplastic syndrome, and mixed-lineage leukemias $[1,2,3,4,5,6,7]$. Most reported cases of $\mathrm{PCH}$ anomaly in 
leukemia patients are in adults; there are only a few reported childhood cases.

Ultrastructural studies of $\mathrm{PCH}$ anomaly have shown that the granules are strongly MPO positive, with variable positivity for PAS, Sudan black, and high-iron diamine, and without an obviously crystalline structure $[5,8]$. Electron microscopic studies suggest that these granules are formed by the fusion of azurophilic granules [9]. Some studies propose that these granules should be considered a morphological variant of Auer bodies [10]; however, the pathophysiology of PCH anomaly remains unknown. The clinical significance of this abnormality has yet to be been determined, because $\mathrm{PCH}$ anomaly is not always associated with disseminated intravascular coagulation or any other characteristic clinical picture. Additional research is required to establish the therapeutic and prognostic relevance of $\mathrm{PCH}$ anomaly.

Key words: Pseudo Chediak-Higashi anomaly, Acute myeloblastic leukemia, Child

\section{Conflict of Interest}

None of authors of this paper has any conflicts of interest, including specific financial interests, relationships, and/or affiliations, relevant to the subject matter or materials included in this manuscript.

\section{References}

1. Didisheim P, Trombold JS, Vandervoort LE, Mibashan RS. Acute promyelocytic leukemia with fibrinogen and factor $\mathrm{V}$ deficiencies. Blood 1964:23:717-728.

2. Van Slyck EJ, Rebuck JW. Pseudo-Chediak-Higashi anomaly in acute leukemia. A significant morphologic corollary. Am J Clin Pathol 1974;62:673-678.
3. Powari M, Varma N, Varma S, Komal HS. Pseudo-Chediak Higashi anomaly in an Indian patient with acute myeloid leukemia (AML-M2). Am J Hematol 2000;65:324-325.

4. Symes PH, Williams ME, Flessa HC, Srivastava AK, Swerdlow $\mathrm{SH}$. Acute promyelocytic leukemia with the pseudoChediak-Higashi anomaly and molecular documentation of $\mathrm{t}(15 ; 17)$ chromosomal translocation. Am J Clin Pathol 1993;99:622-627.

5. Rao S, Kar R, Saxena R. Pseudo Chediak-Higashi anomaly in acute myelomonocytic leukemia. Indian J Pathol Microbiol 2009:52:255-256.

6. Tsai IM, Tsai CC, Ladd DJ. Pseudo-Chediak-higashi anomaly in chronic myelogenous leukemia with myelofibrosis. Am J Clin Pathol 1977;67:608-609.

7. Gallardo R, Kranwinkel RN. Pseudo-Chédiak-Higashi anomaly. Am J Clin Pathol 1985;83:127-129.

8. Ahluwalia J, Kumar V, Trehan A, Marwaha RK, Garewal G. The psuedo-Chediak-Higashi anomaly: an unusual staining pattern in an Indian child with acute myeloid leukemia. Pediatr Hematol Oncol 2004;21:199-202.

9. Tulliez M, Vernant JP, Breton-Gorius J, Imbert M, Sultan C. Pseudo-Chediak-Higashi anomaly in a case of acute myeloid leukemia: electron microscopic studies. Blood 1979;54:863-871.

10. Payne CM, Harrow EJ. A cytochemical and ultrastructural study of acute myelomonocytic leukemia exhibiting the pseudo-Chediak-Higashi anomaly of leukemia and "splinter-type" Auer rods. Am J Clin Pathol 1983;80:216223. 